\title{
Design of Catfish Mass Death Instrument in CV Mina Indo Sejahtera Based on DC Ohmic Plasma
}

\author{
Sari Ayu Wulandari ${ }^{1}$, Wisnu Adi Prasetyanto ${ }^{2}$, Menik Dwi Kurniatie ${ }^{3}$ \\ ${ }^{1,2,3}$ Program Studi Teknik Biomedis Fakultas Teknik Universitas Dian Nuswantoro \\ E-mail: ${ }^{1}$ sari.wulandari@dsn.dinus.ac.id, ${ }^{2}$ wisnuadip@dsn.dinus.ac.id, ${ }^{3}$ nikdwika[a]gmail.com
}

\begin{abstract}
Abstrak
CV. Mina Indo Sejahtera, berikutnya disingkat MIS, adalah sebuah usaha kecil yang bergerak di bidang budidaya lele. MIS memproduksi lele sehat untuk mencukupi kebutuhan eksport ke Timur Tengah. Dalam 1 hari, MIS harus memasok 3000 ekor atau kurang lebihnya 6 ton ikan lele dalam kondisi mati. Salah satu keluhan dari mitra adalah pada pematian masal lele. Dalam pematian ikan lele, mitra kami awalnya mematikannya dengan cara dipukul dan ditumbuk. Namun cara itu menimbulkan masalah, yaitu terdapat beberapa ikan yang dagingnya terkoyak dan remuk. Sehingga dalam melakukan eksport ikan yang dagingnya terkoyak terkena sortir. Selain dengan cara dipukul dan ditumbuk, mitra juga menggarami ikan lele. Namun lele mengeluarkan lendir yang lebih banyak, sehingga membutuhkan waktu 3 menit dalam pengolahan ikan lele. Penggaraman lele berakibat pada penurunan kandungan glikogen, kandungan asam-asam amino, asam lemak bebas, dan biogenik amin, sehingga tidak bisa masuk pada kategori eksport. Karena permasalahan tersebut mitra harus meningkatkan produksinya. Pada beberapa percobaan, pematian lele segera mempunyai kelebihan yaitu mempertahankan texture daging dan meningkatkan umur simpan lele. Alat pematian lele didesign dengan mengguanakan sumber DC, dimana setiap kenaikan $1 \mathrm{~V}$ tegangan, akan menghasilkan -0.813ekor jumlah lele mati. Setiap kenaikan $1 \mathrm{~V}$ tegangan, membutuhkan waktu 43,281 menit untuk mematikan 1ekor jumlah lele mati.
\end{abstract}

Kata kunci: Pematian Lele Massal, Ohmic, Plasma, DC

\section{Abstract}

$C V$. Mina Indo Sejahtera, hereinafter abbreviated as MIS, is a small business engaged in catfish cultivation. MIS produces healthy catfish to meet export needs to the Middle East. In 1 day, MIS must supply 3000 heads or approximately 6 tons of catfish in a dead condition. One complaint from partners was the mass death of catfish. In the death of catfish, our partner initially killed it by being hit and pounded. But the way it causes problems, namely there are some fish whose meat is torn and broken. Exporting fish the meat is torn apart affected by sorting. Apart from being hit and pounded, partners also salted catfish. But catfish secretes more mucus, so it takes 3 minutes in processing catfish. Catfish salting results in decreased glycogen content, amino acid content, free fatty acids, and biogenic amines, so they cannot be included in the export category. Because of these problems partners must increase their production. In some studies, the death of catfish immediately has the advantage of maintaining meat texture and increasing shelf life of catfish. Catfish shutdown devices are designed by using a DC source, where each $1 V$ increase in voltage will result in a record $-0,813$ number of dead catfish. Every $1 V$ increase in voltage, it takes 43.281 minutes to turn off a record number of dead catfish.

Keywords: Mass Death Instrument, Ohmic, Plasma, DC 


\section{PENDAHULUAN}

CV. Mina Indo Sejahtera (mitra kami), berikutnya disingkat MIS, adalah sebuah usaha kecil yang bergerak di bidang budidaya lele yang terletak di J1. Simongan 2 No 39, Kecamatan Semarang Barat Kota Semarang Provinsi Jawa Tengah. Mitra kami merupakan salah satu UMKM yang menerapkan budidaya lele sehat, dengan semua informasi mitra dapat dilihat pada channel youtube dengan alamat channel https://www.youtube.com/channel/UCyV514HY2n KQpokY2reCZCA. Lele yang dibudidayakan di mitra adalah lele sehat, dimana kategori sehat jika cemaran bakteri e-coli dan kandungan antibiotik. UMKM ini bergerak di budidaya ikan lele, dan mempunyai 6 klaster binaan (Gambar 1). MIS mempunyai kolam sendiri, namun mitra memberikan bibit dan pakan pada klaster binaanya, serta melakukan monitoring pada proses budidaya-nya, dan ketika panen, seluruh lele akan dibeli oleh MIS. MIS bertugas menjaga mutu/kualitas lele segar dari klaster plasmanya. Klaster binaan dari MIS adalah UMKM budidaya lele, yang akan bermigrasi dari budidaya lele tidak sehat menjadi budidaya lele sehat. Produk yang dihasilkan mitra menurut responden adalah lele segar yang dikirim ke tengkulak untuk dikumpulkan dan di eksport ke Timur Tengah, serta lele bumbu (Lebum) yang dipasarkan disekitar lokasi UMKM.

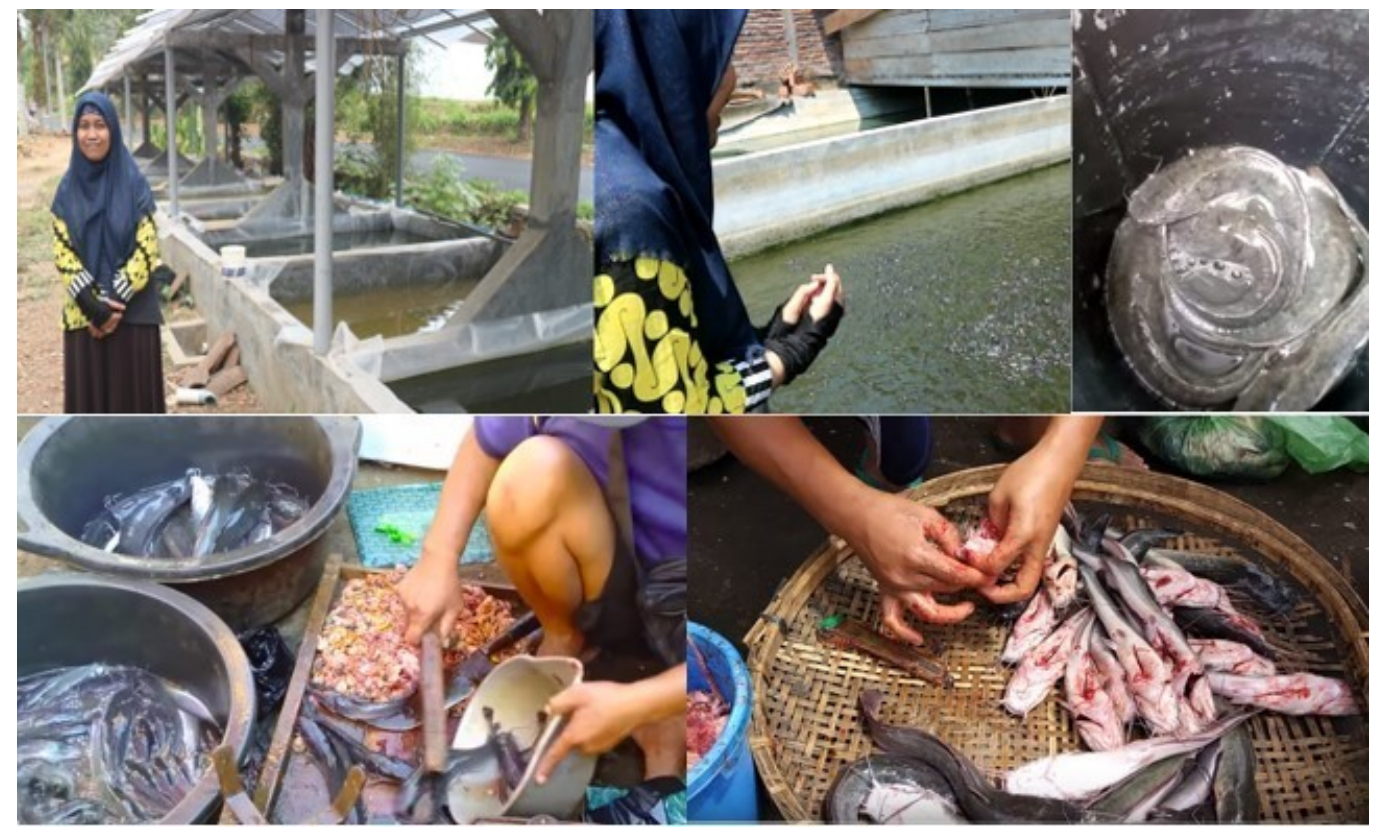

Gambar 1. Survey Lokasi Mitra

MIS memproduksi lele sehat untuk mencukupi kebutuhan eksport ke Timur Tengah. Dalam 1 hari, MIS harus memasok 3000 ekor atau kurang lebihnya 6 ton ikan lele dalam kondisi mati. Salah satu keluhan dari mitra adalah pada pematian masal lele. Dalam pematian ikan lele, mitra kami awalnya mematikannya dengan cara dipukul dan ditumbuk. Namun cara itu menimbulkan masalah, yaitu terdapat beberapa ikan yang dagingnya terkoyak dan remuk. Sehingga dalam melakukan eksport ikan yang dagingnya terkoyak terkena sortir. Selain dengan cara dipukul dan ditumbuk, mitra juga melakukan cara lain yaitu dengan cara menggarami ikan lele dalam suatu wadah. Namun cara ini menimbukan masalah baru, yaitu ketika ikan lele diberikan garam, lele mengeluarkan lendir yang lebih banyak pada tubuhnya, sehingga membutuhkan waktu 3 menit dalam pengolahan ikan lele, selain itu, kandungan garam yang tinggi menyebabkan rasa lele yang berubah. Penggaraman lele berakibat pada penurunan kandungan glikogen, kandungan asam-asam amino, asam lemak bebas, dan biogenik amin, sehingga tidak bisa masuk pada kategori eksport. Karena permasalahan tersebut mitra harus meningkatkan produksinya. Mitra menginginkan seperti eksportir lain yaitu profesional dalam 
pematian ikan. Jadi dalam pematian lele, lele tidak sempat strees sehingga tidak mengeluarkan lendir. Pada beberapa percobaan, pematian lele segera mempunyai kelebihan yaitu mempertahankan texture daging dan meningkatkan umur simpan lele. Dalam hal ini, CV. Mina Indo Sejahtera mempunyai pandangan bahwa dengan cara penyetruman lele dapat meminimalisir masalah yang ada.

Dalam sistem penyetrum ikan, arus listrik dikirim ke ikan melalui dua elektroda. Antara lain yaitu kering (ikan dikeluarkan dari penampung air dan melewati permukaan berlistrik), semi-kering (buffer berisi air) di depan atau ikan disemprot dengan air di antara buffer dan stunner) atau pengejut dapat dikirim dalam air (sementara ikan dipompa melalui tabung). Pengejut bekerja dengan stimulasi pusat saraf yang lebih tinggi untuk "menyebabkan disfungsi pada ikan, baik dengan menginduksi aktivitas epileptiformis atau dengan penghentian total fungsi (Boyland, Brooke and Group, 2017)"(Robb, O'Callaghan, Lines, \& Kestin, 2002). Dalam rainbow trout, ada fase tonik segera setelah arus listrik yang cukup diterapkan, di mana ikan biasanya menjadi kaku dengan beberapa berkedut otot, dan menunjukkan terganggu aktivitas otak yang mengindikasikan ketidaksadaran (Robb et al., 2002). Setelah fase tonik, opercular gerakan berlanjut dan aktivitas otak menunjukkan kembali ke kesadaran. Durasi fase tonik adalah sebagian besar dipengaruhi oleh besaran, durasi, dan frekuensi saat ini; durasi yang lebih lama (atau kematian) bisa dicapai dengan meningkatkan besarnya arus, meningkatkan durasi arus yang diterapkan dan / atau mengurangi frekuensi arus (Robb et al., 2002). Risiko terhadap tingkat kehidupan ikan antara lain; arus listrik, tegangan, atau durasi yang tidak mencukupi dapat menyebabkan pemingsanan yang tidak berhasil. Selain itu, gagal listrik yang tidak berhasil dapat menyebabkan immobilisasi, di mana tubuh tidak bergerak dan tidak responsif dalam tes refleks tetapi aktivitas otak menunjukkan bahwa ikan tetap sadar dan masuk akal to pain (mis. Retter, 2014). Beberapa peneliti telah melakukan percobaan tentang penyetruman ikan. Namun peneliti terdahulu hanya mengenai perbandingan kekuatan kondisi ikan antara ikan satu dengan yang lain setelah diberikan tegangan 18 volt. Pengaruh pemberian kuat arus listrik terhadap tingkat kelulusan hidup. Pada percobaan tentang perbandingan kekuatan kondisi ikan antara ikan satu dengan yang lain setelah diberikan tegangan 18 volt. Untuk objek yang diteliti terdiri dari ikan Lemon dan ikan Lele. Digunakan plat PCB sebagai pengantar arus listrik antara katoda dengan anoda pada dengan tegangan 18 volt, dengan medan listrik yang dihasilkan sebesar $171 \mathrm{v} / \mathrm{m}$. Dari hasil pengamatan respon ikan terhadap medan listrik mempengaruhi perilaku ikan karena terinduksi oleh arus tersebut dan ikan menuju wilayah yang efektif dari elektroda. Ikan lele (Clarias batrachus) lebih kuat ketahanan tubuhnya dalam merespon arus listrik dibandingkan ikan lemon (Lubia caeruleus)(R et al., 2018). Percobaan terdahulu mengenai pengaruh pemberian kuat arus listrik terhadap tingkat kelulusan hidup pada transportasi kering benih Lele. Percobaan dilaksanakan dengan menggunakan Rancangan Acak Lengkap (RAL) dengan 3 perlakuan dan 3 ulangan. Perlakuan yaitu pemberian arus listrik 0,05A (A1), 0,06A (A2), dan 0,07A (A3). Benih ikan yang pingsan dimasukkan di dalam styrofoam lalu diangkut selama 2 jam. Parameter yang diamati meliputi jumlah benih ikan yang pingsan, waktu pulih, dan tingkat kelangsungan hidup benih ikan. Hasil percobaan menunjukkan bahwa pemberian kejutan listrik dengan arus listrik yang berbeda berpengaruh nyata terhadap jumlah benih ikan yang pingsan terbanyak adalah 96,67\% dengan arus listrik 0,07 A. Waktu pulih ikan tercepat pada arus listrik 0,05 A dengan waktu 46,67 detik. Tingkat kelangsungan hidup terbanyak diperoleh dari pemberian arus listrik $0,05 \mathrm{~A}$ dengan jumlah 66,67\%(Primadona et al., 2017). Pada percobaan terdahulu, terdiri dari perbandingan perilaku dan kekuatan ikan dari dua jenis ikan serta percobaan pemingsanan ikan dengan arus listrik cenderung membahas daya tahan ikan serta membandingkan ikan. Penyetruman ikan secara masal memungkinkan adanya sebuah terobosan sebagai alat pemercepat dalam bekerja dalam bidang kuliner untuk diolah dan pendistribusiannya.

Ikan lele mempunyai kelemahan pada bagian tengkuknya. Tengkuk berada tepat diruangan yang lembek setelah tulang tengkorak(Devaere et al., 2006). Tulang tengkorak lele sangatlah kuat, sehingga teknik pematian dengan pemukulan hanya akan mengoyak kulit, tidak mematikan lele(Devaere et al., 2007). Tulang tengkuk sangat dekat dengan otak lele. Ketika 
tulang ini terkoyak, darah akan merendam otak lele dan lele sehingga segera lele akan mati tanpa harus mengoyak tubuh lele(Wilson, Oberle and Oberle, 2013).

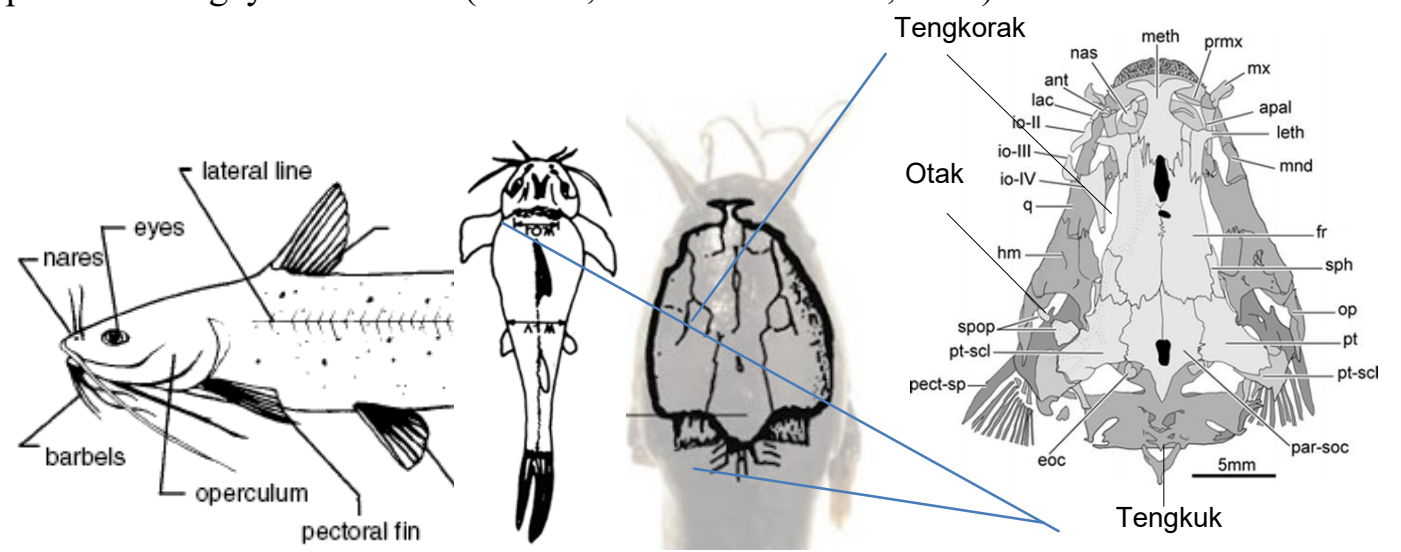

Gambar 2. Pematian Lele Tanpa Sayatan dan Berkualitas

\section{METODE PELAKSANAAN}

\subsection{Tahapan Pelaksanaan}

Secara umum, kegiatan bersama mitra yang menunjukkan langkah-langkah solusi atas permasalahan prioritas mitra, ditunjukkan pada Gambar 3.

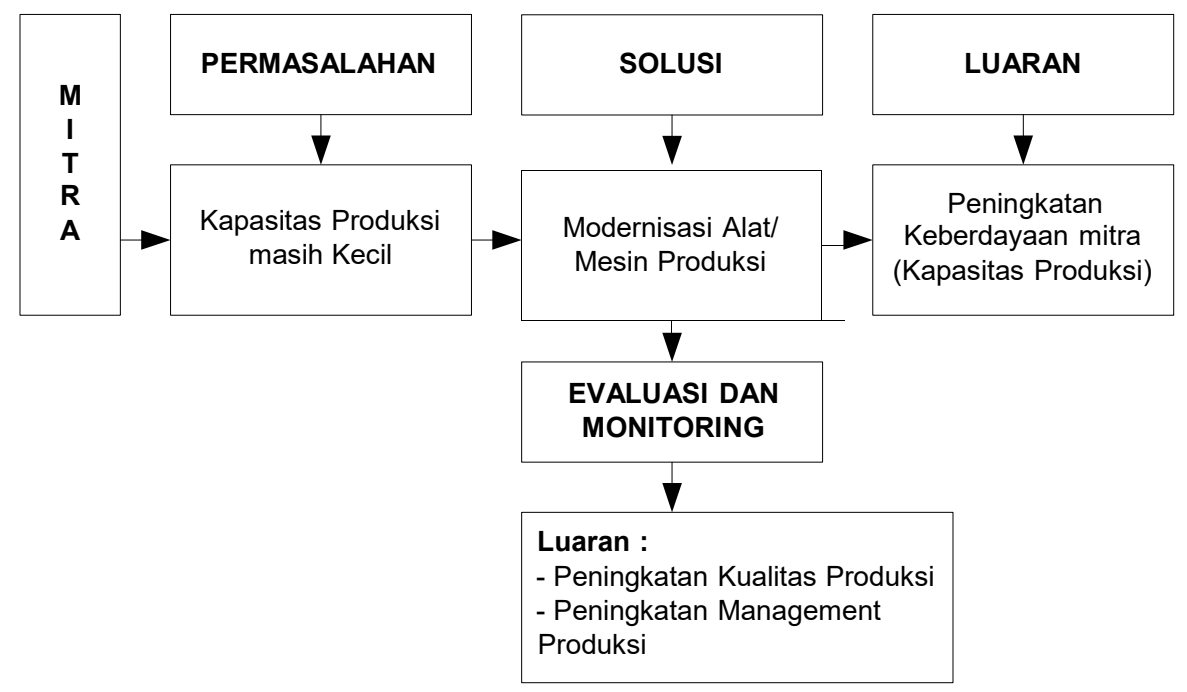

Gambar 3. Kegiatan Rutin Bersama Mitra

Tahapan percobaan diperlihatkan pada Gambar 4. Blok diagram dari metode yang digunakan pada percobaan. ditunjukan pada Gambar 3. Dimulai dari penyiapan alat dan bahan yang meliputi:pipa, seng, driver motor, motor DC, catu DC 220V, Battere Lipo 5V, pegas, resistor, kapasitor, box compartment, magnetic valve, selang air, mini fan, motor servo, mikrokontroller, webcam, kabel, sensor ultrasonic, load sensor, proximity, LCD, dan aktuator. 
Abdimasku, Vol. 3, No. 2, Mei 2020: 48-56

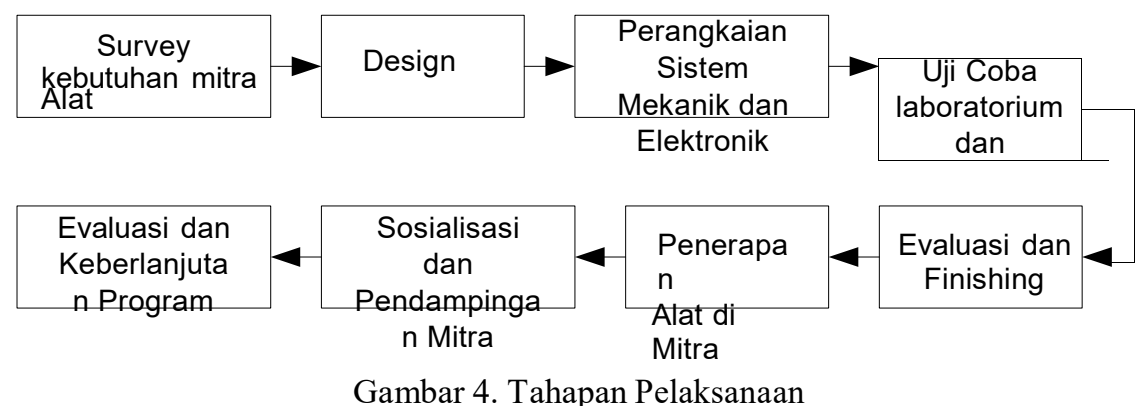

Tahap selanjutnya yaitu pembuatan prototipe yang dibagi 3 bagian yaitu: sistem kontrol, sistem mekanis dan design program. Berikutnya adalah melakukan analisis sistem mengunakan peralatan multimeter, sofware isis dan solidwork. Setelah pengerjaan prototipe selesai akan dilakukan pengujian sistem control dan uji mekanik. Pengujian mekanik menggunakan tensile test agar dapat mengetahui kekuatan tarikan pada design mekanik. Pengujian sistem kontrol akan diuji time respon alat saat bekerja dan repeatability dari tiap sensor. Setelah itu dilakukan proses pendampingan kepada mitra, dimana mitra diberikan pengetahuan dan ketrampilan untuk pemakaian alat dan tata cara penggunaan. Akhir dari kegiatan dilakukan pengujian pada lokasi mitra, dan evaluasi pelaksanaan program.

\subsection{Rancang Bangun Alat}

Pada tahap pertama, dilakukan pengumpulan informasi dan referensi dari percobaan terdahulu. Beberapa hal yang termasuk dalam kebutuhan percobaan yaitu pembuatan alur percobaan (proses percobaan), tempat dan sumber pengumpulan data, metode yang akan digunakan dalam membahas pengaruh tegangan terhadap pematian masal ikan lele serta tata cara pengujian untuk percobaan tersebut.

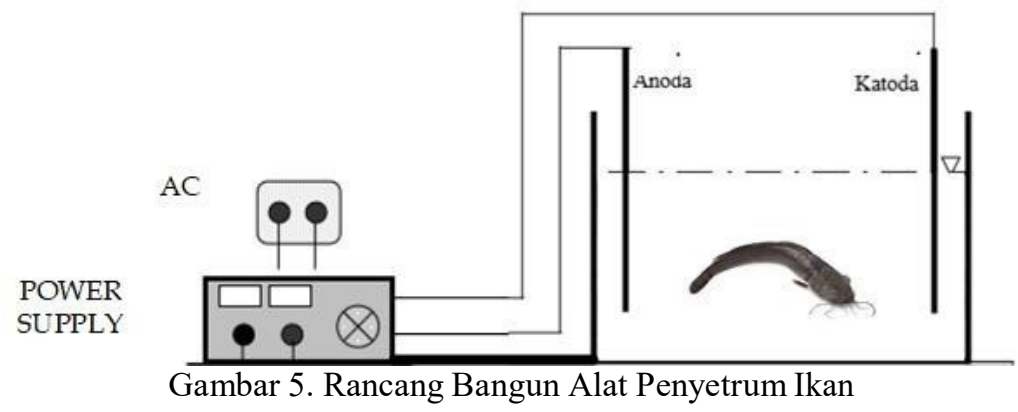

Berdasarkan pada blok diagram umum alat penyetrum ikan (Gambar 3.2) dijelaskan bahwa listrik yang bersumber dari AC lalu dimasukan kedalam power suppy sehingga listrik berubah menjadi searah (DC). Power supply berperan sebagai pengatur tegangan yang akan mengalir ke elektroda (-) dan (+) sebagai penyetrum ikan. Didalam box ikan dipasangkan 2 lempengan konduktor listrik sebagai katode $(+)$ dan anode (-). Fungsinya adalah menyengatkan listrik didalam air pada box.

\subsection{Percobaan Peningkatan Tegangan}

Percobaan peningkatan tegangan pada pematian masal ikan lele dilakukan 4 percobaan. Percobaan pertama menggunakan arus 15 A dengan tegangan $6 \mathrm{~V}$. Percobaan kedua menggunakan arus $15 \mathrm{~A}$ dengan tegangan $12 \mathrm{~V}$. Percobaan ketiga menggunakan arus $15 \mathrm{~A}$ dengan tegangan $24 \mathrm{~V}$. Dan yang terakhir percobaan menggunakan arus $15 \mathrm{~A}$ dengan tegangan $35 \mathrm{~V}$.

\subsection{Analisis Menggunakan Metode Interpolasi}

Analisis menggunakan metode interpolasi merupakan tahapan untuk mendapatkan garis linier klaster dari setiap percobaan. Berikut contoh untuk mengetahui hasil analisis menggunakan metode interpolasi. 


\section{HASIL DAN PEMBAHASAN}

\subsection{Sistem Mekanik dan Elektronik}

Implementasi dari alat pematian lele masal ini dimulai dengan tahap percobaan peningkatan tegangan. Pada tahap percobaan peningkatan tegangan, dilakukan dengan cara meningkatkan tegangan dari perangkat charger atau power supply. Listrik yang bersumber dari AC lalu dimasukan kedalam power suppy sehingga listrik berubah menjadi searah (DC). Power supply berperan sebagai pengatur tegangan yang akan mengalir ke elektroda (-) dan (+) sebagai penyetrum ikan. Didalam box ikan dipasangkan 2 lempengan konduktor listrik sebagai katode $(+)$ dan anode (-). Fungsinya adalah menyengatkan listrik didalam air pada box.

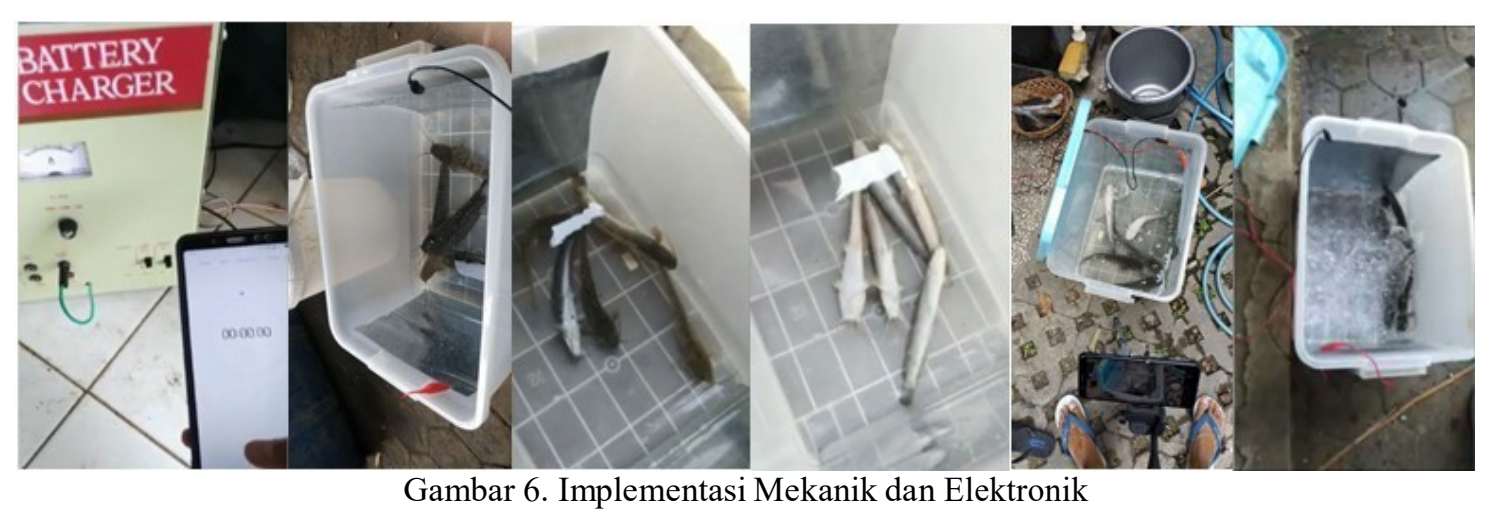

\subsection{Sistem Mekanik dan Elektronik}

Pada pelaksanaan pengabdian ini, dilakukan pengambilan data jumlah lele yang mati beserta lama waktu yang dibutuhkan. Data pengambilan jumlah lele yang mati beserta waktu yang dibutuhkan diperlihatkan pada Tabel 1. Pada tabel tersebut, akan dilakukan pengambilan data selama 15 menit. Hal ini dilakukan karena pada CV. Mitra Mina Indo Sejahtera menggunakan waktu 15 menit untuk mematikan 5 ekor lele, dimana waktu yang dibutuhkan untuk membunuh lele per ekornya adalah 3 menit.

Tabel 1. Data Peningkatan Tegangan Terhadap Jumlah Kematian Lele

\begin{tabular}{|c|c|}
\hline Tegangan ( V) & Tingkat Kematian Lele ( Ekor ) \\
\hline 6 & 0 \\
\hline 12 & 1 \\
\hline 24 & 4 \\
\hline 35 & 5 \\
\hline
\end{tabular}

Dari hasil percobaan tersebut dapat dilihat bahwa pada tegangan $6 \mathrm{~V}$ belum terdapat lele yang mati selama 15 menit. Sedangkan pada tegangan $12 \mathrm{~V}$, penyetruman selama 15 menit terdapat 1 ekor lele yang mati. Kemudian pada tegangan $24 \mathrm{~V}$, penyetruman selama 15 menit terdapat 4 ekor lele yang mati. Dan pada tegangan $35 \mathrm{~V}$, penyetruman selama 15 menit barulah semua lele pada mati. Grafik trenline dari pengaruh antara jumlah lele peningkatan tegangan terhadap jumlah lele yang mati diperlihatkan pada Gambar 7. 


\section{Lele Mati}

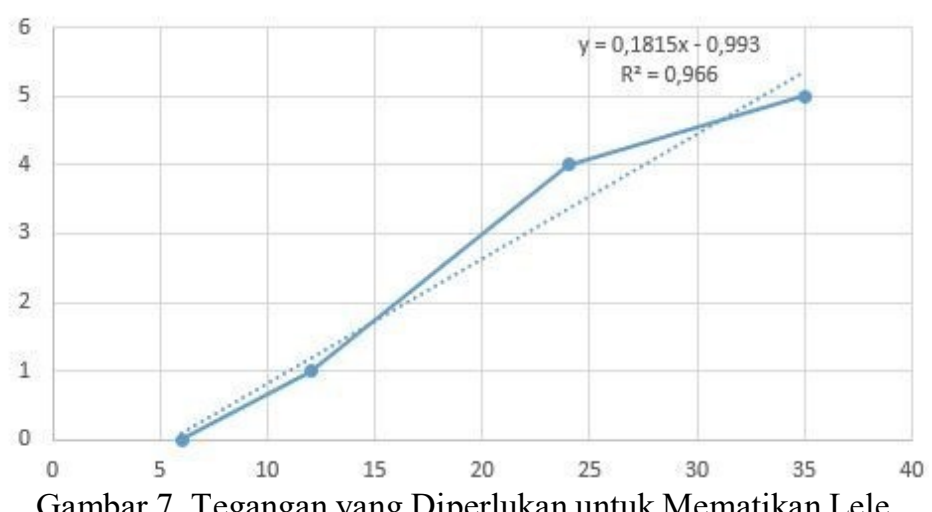

Gambar 7. Tegangan yang Diperlukan untuk Mematikan Lele

Pada Gambar 7 didapatlah titik ciri dari percobaan peningkatan tegangan. Selain itu didapat juga garis linear serta persamaan y dari hasil percobaan peningkatan tegangan.

$$
\mathrm{Y}=0,1815 \mathrm{X}+-0,993(1)
$$

Pada persamaan 1 didapatkan hasil bahwa, setiap kenaikan $1 \mathrm{~V}$ tegangan, akan menghasilkan -0.813 ekor jumlah lele mati. Untuk mendapatkan kebutuhan jumlah tegangan ketika lele mati yang dibutuhkan untuk ekspor sejumlah 3000 ekor, maka membutuhkan perhitungan sebagai berikut :

Maka : Ketika $Y=3000$

$$
\begin{aligned}
& Y=0,1815 X+-0,993 \\
& 3000=0,1815 X+-0,993 \\
& 3000,993=0,1815 X \\
& X=- \\
& X=16534,38
\end{aligned}
$$

Tabel 2. Data Waktu Kematian Lele Terhadap Peningkatan Tegangan

\begin{tabular}{|c|c|}
\hline Tegangan ( V) & Waktu ( Menit ) \\
\hline 6 & - \\
\hline 12 & $8^{\prime} 18^{\prime \prime}$ \\
\hline 24 & $3^{\prime} 20^{\prime}$ \\
\hline 35 & 2' 6' $^{\prime}$ \\
\hline
\end{tabular}

Dari hasil percobaan tersebut dapat dilihat bahwa jika dilakukan pengukuran untuk tiap lele yang mati, maka pada tegangan $6 \mathrm{~V}$, lele tidak ada yang mati dalam kurun waktu 15 menit. Sedangkan pada tegangan $12 \mathrm{~V}$, semua satu ekor lele mati setiap 8' 18'. Lalu pada tegangan 24 V, satu ekot lele mati setiap 3' 20'. Dan pada tegangan $35 \mathrm{~V}$, satu ekor lele mati setiap 2' 6'. Grafik trenline dari pengaruh antara jumlah lele peningkatan tegangan terhadap jumlah lele yang mati diperlihatkan pada Gambar 8. 


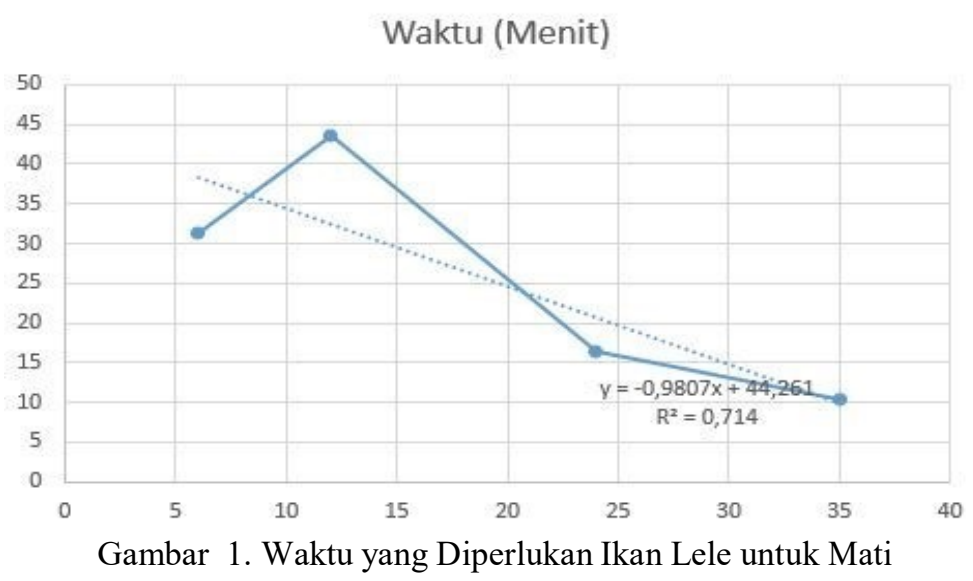

Pada Gambar 4.3 didapatlah titik ciri dari percobaan peningkatan tegangan berdasarkan waktu untuk mematikan lele secara masal. Selain itu didapat juga garis linear serta persamaan y dari hasil percobaan peningkatan tegangan.

$$
\mathrm{Y}=-0,9807 \mathrm{X}+44,261
$$

Pada persamaan 2 didapatkan hasil bahwa, setiap kenaikan $1 \mathrm{~V}$ tegangan, membutuhkan waktu 43,281 menit untuk mematikan 1 ekor jumlah lele mati. Untuk mendapatkan kebutuhan jumlah tegangan ketika lele mati yang dibutuhkan untuk ekspor sejumlah 3000 ekor, maka membutuhkan perhitungan sebagai berikut :

$$
\begin{aligned}
& \text { Didapat : } \quad \mathrm{Y}=-0,9807 \mathrm{X}+44,261 \\
&=0,714 \\
& \text { Maka : Ketika } \mathrm{Y}=3 \text { ( menit }) \\
& \mathrm{Y}=-0,9807 \mathrm{X}+44,261 \\
& 3=-0,9807 \mathrm{X}+44,261 \\
&-41,261=-0,9807 \mathrm{X} \\
& \mathrm{X}= \\
& \mathrm{X}=42,07
\end{aligned}
$$

\section{KESIMPULAN DAN SARAN}

Kesimpulan yang didapatkan dari pengabdian yang berjudul "Peningkatan Produktifitas Mitra Mina Indo Sejahtera Pada Pematian Massal Ikan Lele Menggunakan Mesin Ohmic Plasma" adalah alat pematian lele ini didesign dengan menggunakan sumber DC, dimana setiap kenaikan $1 \mathrm{~V}$ tegangan, akan menghasilkan -0.813 ekor jumlah lele mati. Setiap kenaikan $1 \mathrm{~V}$ tegangan, membutuhkan waktu 43,281 menit untuk mematikan 1 ekor jumlah lele mati.

\section{UCAPAN TERIMA KASIH}

Makalah ini dibiayai dari dana penelitian internal Universitas Dian Nuswantoro, Tahun anggaran 2019-2020.

\section{DAFTAR PUSTAKA}

[1]. Boyland, N., Brooke, P. and Group, A. A. C. W. (2017) Farmed fish welfare during 
slaughter.

[2]. Devaere, S. et al. (2006) 'Morphology of the cranial system of Platyclarias machadoi: Interdependencies of skull flattening and suspensorial structure in Clariidae', Zoomorphology, 125(2), pp. 69-85. doi: 10.1007/s00435-005-0012-7.

[3]. Devaere, S. et al. (2007) 'Phylogeny of the African representatives of the catfish family Clariidae (Teleostei, Siluriformes) based on a combined analysis: Independent evolution towards anguilliformity', Journal of Zoological Systematics and Evolutionary Research, 45(3), pp. 214-229. doi: 10.1111/j.1439-0469.2006.00399.x.

[4]. Primadona, R. et al. (2017) 'Pengaruh Pemberian Kuat Arus Listrik Terhadap Tingkat Kelulusan Hidup pada Transportasi Kering Benih Ikan Lele ( Clarias sp .)', 6(2), pp. 145152.

[5]. R, S. et al. (2018) 'Perbandingan Kekuatan Ikan Lemon (Lubia Caeruleus) Dengan Ikan Lele (Clarias Batrachus) Pada Tegangan 18 Volt', Gravity: Jurnal Ilmiah Penelitian dan Pembelajaran Fisika, 4(2), pp. 57-66. doi: 10.30870/gravity.v4i2.4033.

[6]. Wilson, A. D., Oberle, C. S. and Oberle, D. F. (2013) 'Detection of off-flavor in catfish using a conducting polymer electronic-nose technology.', Sensors (Basel, Switzerland), 13(12), pp. 15968-15984. doi: 10.3390/s131215968.

[7]. M. Mahyuddin, Kholish, S.Pi., Panduan Lengkap Agribisnis Lele. Niaga Swadaya, 2013.

[8]. N. Boyland, P. Brooke, and A. A. C. W. Group, "Farmed fish welfare during slaughter," 2017.

[9]. S. R et al., "Perbandingan Kekuatan Ikan Lemon (Lubia Caeruleus) Dengan Ikan Lele (Clarias Batrachus) Pada Tegangan 18 Volt," Gravity J. Ilm. Penelit. dan Pembelajaran Fis., vol. 4, no. 2, pp. 57-66, 2018.

[10]. R. Primadona et al., "Pengaruh Pemberian Kuat Arus Listrik Terhadap Tingkat Kelulusan Hidup pada Transportasi Kering Benih Ikan Lele ( Clarias sp .)," vol. 6, no. 2, pp. 145152, 2017.

[11]. Sari Ayu Wulandari, F. O. S., F. K. Adi, And R. Tsuroya, "Automatic Pet Cow- Feeder (Apec), Solusi Optimalisasi Pakan Peternakan Sapi Potong Penghasil Energi Biogas Madani Di Laka Farm Tegal Bidang," Vol. 00542, 2013.

[12]. E. Kartikadarma, S. Wijayanti, S. A. Wulandari, and F. A. Rafrastara, "Principle Component Analysis for Classification of the Quality of Aromatic Rice," vol. 1, no. 8, 1947.

[13]. S. A. Wulandari, Arifin, H. Widiyandari, and A. Subagio, "Synthesis and characterization carboxyl functionalized Multi- Walled Carbon Nanotubes (MWCNT-COOH) and NH2 functionalized Multi-Walled Carbon Nanotubes (MWCNT- NH2)," J. Phys. Conf. Ser. 1025, vol. 1025, 2018.

[14]. S. A. Wulandari, W. A. Prasetyanto, and R. Tjahyono, "Perbandingan Forecasting Metode Regresi Non-Linear Polinomial dengan Logika Fuzzy pada Pemetaan Potensi Bisnis Lampu Berbasis Reduse, Reuse dan Recycle," ABDIMASKU J. Pengabdi. Masy., vol. 1, no. 2, pp. 71- 79, 2018.

[15]. S. A. Wulandari, M. D. Kurniatie, and D. Nurcipto, "Pelatihan Peningkatan Mutu Produk Recycle Speaker Pada UKM Nusantara Recycle Centre,” vol. 2, no. 2, pp. 42-50, 2019.

[16]. S. A. Wulandari, T. L. Ahmad, D. Santari, And N. Agassy, "Pengolahan Limbah Ikan Melalui Penerapan Teknologi Pengering Limbah Ikan Bertenaga Hybrid Sebagai Upaya Meningkatkan Nilai Ekonomi Pendapatan Ukm Ikan Asap Di Bandarharjo Semarang," Pp. 1-11, 2013. 